\title{
An Investigation of Flexural Behavior of Pure and Hybrid Wood Composite Panels Using Weibull Analyses
}

\section{Istraživanje savijanja čistih i hibridnih kompozitnih drvnih ploča uz pomoć Weibullove analize}

\author{
Original scientific paper - Izvorni znanstveni rad \\ Received-prispjelo: 18. 8. 2020. \\ Accepted-prihvaćeno: 14. 1. 2021. \\ UDK: $630 * 812.71 ; 630 * 863$ \\ https://doi.org/10.5552/drvind.2021.2032
}

\author{
(C) 2021 by the author(s). \\ Licensee Faculty of Forestry and Wood Technology, University of Zagreb. \\ This article is an open access article distributed \\ under the terms and conditions of the \\ Creative Commons Attribution (CC BY) license.
}

\begin{abstract}
The production of inexpensive wood products compared to their strength is important both in terms of economy and meeting the expectations of users. For this purpose, the use of hybrid wood products is increasing in the furniture industry. With the hybridization process, relatively cheap and flimsy material is combined with a material that has a stronger structure. Thus, stronger bonded material is manufactured cheaper. In this study, the flexural behavior of pure and hybrid wood composite panels, which were prepared by applying longitudinal jointing techniques from different wood materials, was investigated. In this context, pure chipboard, pure medium density fiberboard (MDF), chipboard-east beech and MDF-east beech hybrid wood composite panels were produced. During the hybridization process, oriental beech was combined by using the self-grooving technique in three different numbers as one row, two rows, and three rows. Flexural test results were analyzed according to the Weibull distribution method. The results of the analyses showed that the hybridization process increased the flexural strength and flexural modulus of pure wood panels by up to $214 \%$, and $95 \%$, respectively.
\end{abstract}

Keywords: flexural behavior; chipboard; MDF; oriental beech, Weibull analysis

SAŽETAK • Proizvodnja jeftinijih proizvoda od drva uz očuvanje njihove čvrstoće ima veliku važnost u ekonomskom smislu i u smislu ispunjavanja korisničkih očekivanja. Rezultat tog nastojanja jest sve veća uporaba hibridnih proizvoda od drva u industriji namještaja. Postupkom hibridizacije relativno jeftin i krhak materijal kombinira se s materijalom jače strukture te se na taj način postiže čvršći a jeftiniji materijal. U ovom je radu istraženo ponašanje čistih i hibridnih kompozitnih drvnih ploča pri savijanju, proizvedenih uzdužnim lijepljenjem različitoga drvnog materijala. Za potrebe istraživanja izrađene su čista ploča vlaknatica srednje gustoće (MDF) $i$ hibridne kompozitne ploče od iverice i bukovine te od MDF ploče i bukovine. Tijekom postupka hibridizacije bukovi su elementi povezivani uz pomoć utora, a izrađeni su uzorci imali jedan, dva ili tri bukova elementa. Rezultati ispitivanja svojstava ploča pri savijanju analizirani su uz pomoć Weibullove distribucije. Pokazalo se da je postupak hibridizacije pridonio povećanju čvrstoće ploča na savijanje za $214 \%$, a modula elastičnosti za $95 \%$.

Ključne riječi: savijanje; iverica; MDF; bukovina; Weibullova analiza

\footnotetext{
Author is researcher at Usak University, Banaz Vocational High School, Department of Forestry, Usak, Turkey.

2 Author is researcher at Usak University, Department of Mechanical Engineering, Engineering Faculty, Usak, Turkey.
} 


\section{INTRODUCTION}

\section{UVOD}

Furniture used in houses or offices is faced with various loads, either directly or indirectly, depending on the place of use. These loads cause tensile, compression and bending deformations in the elements forming the furniture and their connection points. As a result of these deformations, damages occur such as breakage of wood joints or wooden structural elements. To fully understand the structural characteristics of furniture, it is necessary to analyze the mechanical behavior of joints used in wooden structures. The length, stiffness, and strength of the joints applied in wooden constructions affect the strength of the furniture system.

In the furniture industry, joints are used to connect furniture elements, reuse solid and composite wood materials that would be wasted, or to obtain larger surfaces. Straight jointing, lamp jointing, foreign slat jointing, self-slating jointing, dowel joining and edge joining are commonly used. The joining points of the wooden structural elements formed by joining are the potential error starting regions for the structure. The joining performance should be examined for the strength of the structure. Joints are usually regions where stresses are concentrated (Eshaghi et al., 2013). Furniture joints are also subjected to axial, tensile or compression, shear, and bending or rotational forces. This necessitates the use of more resistant and stronger joints.

Dourado et al. (2019) studied the bending performance of two different wood panels, which they joined by using wood dowel connection, experimentally and numerically. Cagatay et al. ( 2012) compared the bending moment capacity and elasticity of T-type furniture joints by applying different wood materials and joining methods. Likos et al. (2012) investigated the effects of tenon geometry, grain orientation, and shoulder-length on the bending moment capacity and moment rotation of wood structures. Baszen (2017) discussed the joint flexibility problem in wood light-frame structures and presented the results on rotational and axial stiffness of joint in wood light-frame structures. Also, adhesive bonding is more frequently used than mechanical joints in some wooden structures. Edgards et al. (2017) examined the flexural performance of wood-based sandwich panels adhesively bonded under four-point bending loading. Augeard et al. (2018) investigated the mechanical behavior of bonded hybrid wood-concrete beams and panels, experimentally and analytically.

Oriental beech (Fagus orientalis L.), Scotch pine (Pinus slyvestris L.), Oak (Quercus borealis L.), chestnut (Castanea sativa mill), Oriental black sea fir (Abies nordmanniana) and walnut (Juglans regia L.) massifs were used in the studies related to wood end to endgrain joint (Efe et al., 2015). Using these massifs, many kinds of joining operations such as polyvinyl acetate (PVAc) glue mortise bonding (Altun et al., 2010), dovetail length bonding (Efe et al., 2014), L type lamp tenon bonding (Kasal et al., 2015), dowel and foreign slat hybrid jointing (Tas, 2011), dowel and lamp joint- ed hybrid jointing (Ozgan and Kap, 2008) were performed and their joint performances were examined.

In the past, the scattering of experimental data was relatively insignificant because manufacturers used large safety factors in design. However, increasing material costs and dimensional constraints in design prevented from using large safety factors. In particular, the designer must consider the weakest member of the population, not only the mean, mode or other central tendency of the distribution. The scatter in the experimental values measured from mechanical tests for wood materials is usually described by Weibull statistical distribution, either two or three-parametric. In this study, the flexural strength and flexural modulus of elasticity of pure and hybrid wood panels under threepoint bending load were investigated. For pure wood panels, wood coated chipboard and medium-density fiberboard (MDF) board materials were used. To produce hybrid composite panels, chipboard and MDF plates were individually combined with oriental beech (Fagus orientalis L.) using a self-grooving technique. During the production of hybrid wood composite panels, oriental beech was used as one row, two rows, and three rows, and it reinforced the weaker chipboard and MDF panels in strength. To understand the effect of the hybridization process on the flexural strength of wood panels, the test results were compared with the flexural test results of pure chipboard and pure MDF wood material. Also, two-parametric Weibull statistical analysis is used to get the variability of flexural strength and flexural modulus of pure and hybrid wood composite panels. According to the Weibull analysis, the test result, which has an $80 \%$ reliability percentage, is accepted as the main value.

\section{MATERIALS AND METHODS} 2. MATERIJALI I METODE

\subsection{Wood and wood-based composite materials 2.1. Drvo i drvnokompozitni materijali}

In this study, oriental beech (Fagus orientalis L.) wood, which is widely used in industry, was used as a reinforcement phase in the hybridization process. Chipboard coated with synthetic resins, manufactured according to TS EN 312-2 standard, and medium density fiberboard (MDF) coated with synthetic resins, produced according to TS 64-3 EN 622-3 standard, were used as wood-based composite material. Beech timber material was provided from a timber company located in Karabük in Turkey. In the selection of beech wood material, care was taken to ensure that the timber was flawless, that the fibers of timber were smooth, knot-free, and had no fungus or insect damage. The physical properties and mechanical strengths of wood and wood-based composite materials, which were used to produce hybrid wood panels, are given in Table 1.

\subsection{Adhesive material}

\subsection{Ljepilo}

Kronen Holzleim D4 polyvinyl acetate glue was used for the bonding of self-grooving test specimens. It 
..... Karaman, Balcioglu: An Investigation of Flexural Behavior of Pure and Hybrid Wood...

Table 1 Physical and mechanical properties of used wood and wood-based materials (Cai and Ross, 2010)

Tablica 1. Fizička i mehanička svojstva upotrijebljenog drva i materijala na bazi drva (Cai and Ross, 2010.)

\begin{tabular}{|c|c|c|c|c|c|}
\hline $\begin{array}{c}\text { Material type } \\
\text { Vrsta materijala }\end{array}$ & $\begin{array}{c}\text { Humidity, } \\
\text { \% } \\
\text { Sadržaj } \\
\text { vode, \% }\end{array}$ & $\begin{array}{l}\text { Density, } \\
\text { g/cm } \\
\text { Gustoća } \\
\mathrm{g} / \mathrm{cm}^{3}\end{array}$ & $\begin{array}{l}\text { Dry density, } \mathbf{g} / \mathrm{cm}^{3} \\
\text { Gustoća apsolutno } \\
\text { suhoga drva, } \mathrm{g} / \mathrm{cm}^{3}\end{array}$ & $\begin{array}{c}\text { Flexural } \\
\text { strength, MPa } \\
\text { Čvrstoća } n a \\
\text { savijanje, } \mathrm{MPa}\end{array}$ & $\begin{array}{c}\text { Modulus of } \\
\text { elasticity, MPa } \\
\text { Modul } \\
\text { elastičnosti, } M P a\end{array}$ \\
\hline Oriental beech / bukovina & 8.42 & 0.65 & 0.69 & 120 & 13400 \\
\hline MDF lam / MDF lamela & 6.51 & 0.69 & 0.70 & 120 & 4435 \\
\hline Chipboard lam / lamela od iverice & 5.93 & 0.78 & 0.40 & 27 & 4347 \\
\hline
\end{tabular}

is an odorless and fireproof, easy to apply, quick hardening glue that can be used in cold temperatures and quickly solidified. However, mechanical resistance of PVAc D4 glue decreases with increasing heat. It loses bonding resistance capacity over $70{ }^{\circ} \mathrm{C}$. On the condition that the adhesive is applied to only one surface, using $150 \mathrm{~g} / \mathrm{m}^{2}-200 \mathrm{~g} / \mathrm{m}^{2}$ adhesive seems to be suitable. The physical properties of this glue were determined as press pressure of $0.1 \mathrm{MPa}-0.8 \mathrm{MPa}, \mathrm{pH} 3.5$, viscosity (at $20^{\circ} \mathrm{C}$ ) $16000 \mathrm{MPa} \cdot \mathrm{s}-15000 \mathrm{MPa} \cdot \mathrm{s}$, density $1.08 \mathrm{~g} / \mathrm{cm}^{3}$. It is stated by the manufacturer that the wood bonding time is 35-40 minutes at room temperature. TS 3891 standard procedure was used for applying PVAc D4 adhesive (Tankut and Tankut, 2009).

\subsection{Preparing of flexural test samples}

\subsection{Priprema uzoraka za savijanje}

The oriental beech wood materials, which were used for reinforcement phase, were first stacked in planks under suitable conditions for six months. Afterward, they were cut to appropriate dimensions and, with fir laths between them, kept for a year in a ventilated central heating system with no sunlight. After this stage, oriental beech planks were machined into final dimensions of $18 \mathrm{~mm} \times 36 \mathrm{~mm} \times 720 \mathrm{~mm}$ by using a thickness planer and circular sawing machine, respectively. On the edge surfaces of wooden materials, the width joining parts were prepared by opening a $1 / 3$ width and $1 / 2$ depth of the piece thickness in the wood profile machine. The dimensions of the oriental beech joint element used in the study are given in Figure 1.

In the experimental study, wood-based chipboard and MDF were used as the material to be strengthened.

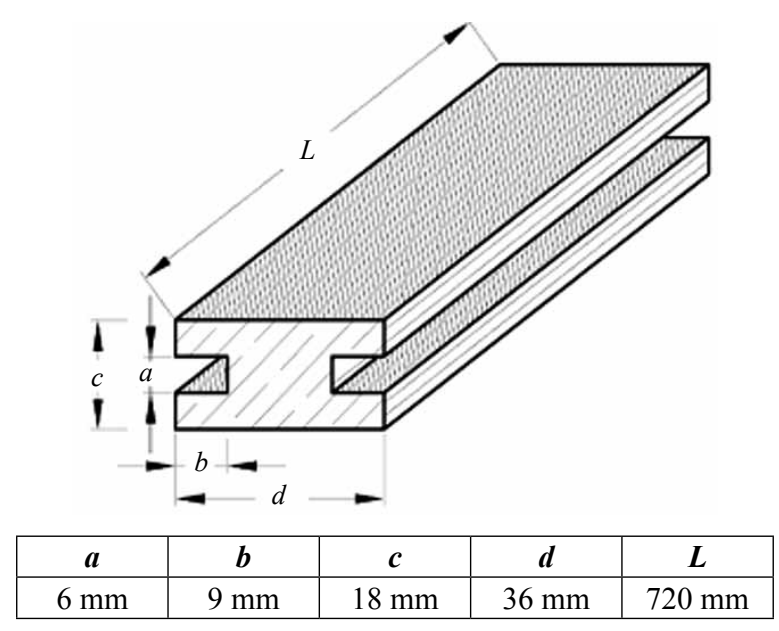

Figure 1 Oriental beech width joint element used in the production of hybrid panels

Slika 1. Širinski spojni elementi bukovine upotrijebljeni za proizvodnju hibridnih ploča

Thus, both endurances had to be increased and waste chipboard and MDF materials had to be reused in combination with more resistant materials. To this scope, chipboard and MDF materials were subjected to hybridization, where they were joined with oriental beech wood in one row, two rows, and three rows. A general view of the self-groove wood-based composite parts used in joints is given in Figure 2. The dimensions of the self-groove elements used in the edge and mid part vary depending on the number of rows of joints. The dimensions of the self- groove chipboard and MDF elements are given in Table 2.

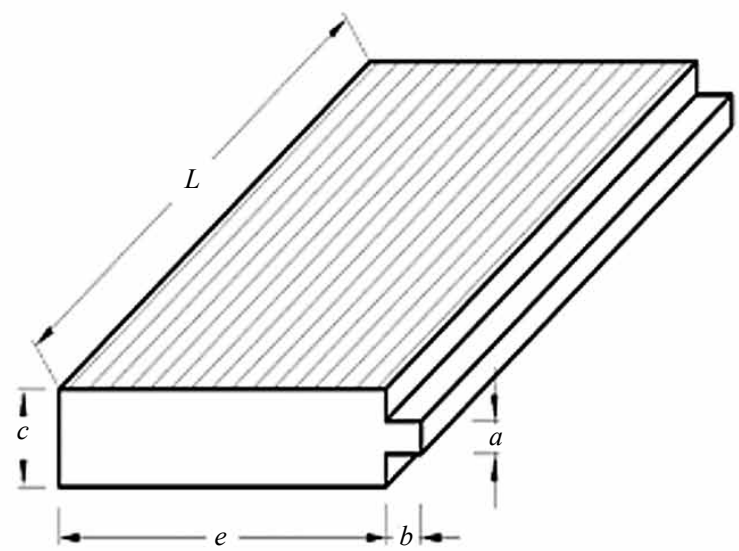

a)

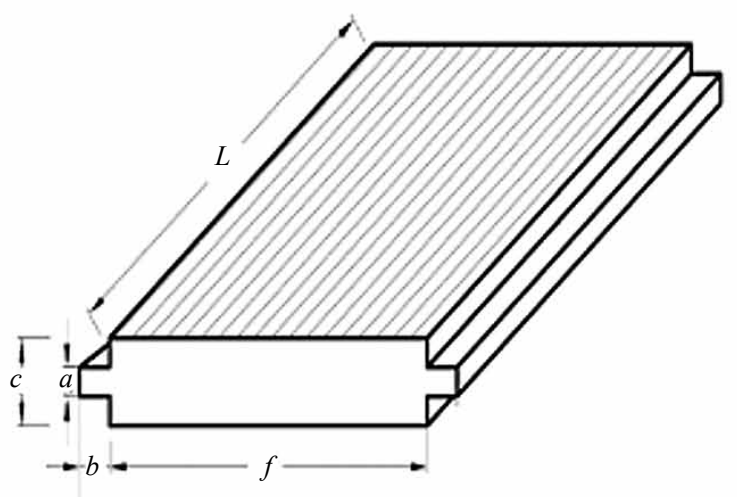

b)

Figure 2 Self-groove wood-based composite parts used in joints for: a) edge part and b) mid part

Slika 2. Dijelovi kompozita s utorom upotrijebljeni za spajanje: a) rubni dio, b) srednji dio 
Table 2 Dimensions of self- groove chipboard and MDF elements

Tablica 2. Dimenzije elemenata iverice i MDF ploče

\begin{tabular}{|l|c|c|c|c|c|}
\hline Type of element / Vrsta elementa & $\boldsymbol{a , ~ m m}$ & $\boldsymbol{b}, \mathbf{m m}$ & $\boldsymbol{c}, \mathbf{m m}$ & $\boldsymbol{e}, \mathbf{m m}$ & $\boldsymbol{f}, \mathbf{m m}$ \\
\hline Edge part for one row / rubni dio za ploče s jednim bukovim elementom & 6 & 9 & 18 & 162 & - \\
\hline Edge part for two rows / rubni dio za ploče s dva bukova elementa & 6 & 9 & 18 & 96 & - \\
\hline Edge part for three rows / rubni dio za ploče s tri bukova elementa & 6 & 9 & 18 & 63 & - \\
\hline Mid part for two rows / središnji dio za ploče s dva bukova elementa & 6 & 9 & 18 & - & 144 \\
\hline Mid part for three rows / središnji dio za ploče s tri bukova elementa & 6 & 9 & 18 & - & 78 \\
\hline
\end{tabular}

During the preparation of test specimens, selfgroove jointing was used as one of the conventional glue bonding techniques. PVAc-D4 glue was used for conventional glue bonding. Taking into consideration the recommendations of the manufacturer, PVAc-D4 glue was applied to the joint cross-sections, groove surfaces and groove nests with an average amount of glue of $160 \mathrm{~g} / \mathrm{m}^{2}-180 \mathrm{~g} / \mathrm{m}^{2}$ and then the elements were bonded to each other. The glued parts were firmly squeezed together and then allowed to dry under room conditions and under pressure. The prepared hybrid wood panels are illustrated in Figure 3. The final dimensions of the dried test specimens were $18 \mathrm{~mm} \times$ $360 \mathrm{~mm} \times 720 \mathrm{~mm}$.

\subsection{Three-point bending test}

2.4. Ispitivanje savijanja u tri točke

Static three-point bending tests were carried out on a universal tester according to TS 2478 standards. This standard specifies a method for determining the modulus of elasticity of wood in static bending by measuring deflection in the bending area (TSE 2478, 1976). Test samples with the dimensions of $18 \mathrm{~mm} \times$ $360 \mathrm{~mm} \times 720 \mathrm{~mm}$ were kept in the air-conditioned cabinet with a temperature of $20^{\circ} \mathrm{C}$ and $65 \%$ relative humidity until they reached constant weight before the flexural test. Also, the equilibrium moisture value of the test atmosphere of $12 \%$ was measured. Flexural tests were performed on a U-test $50 \mathrm{kN}$ computer-controlled universal testing machine. The speed of the loading-head was set to be $2 \mathrm{~mm} / \mathrm{min}$. Load-displacement data were recorded for each sample during the test depending on time. Figure 4 shows, schematically, the three-point bending test setup. In the flexural tests, ten test replicates were performed for pure and hybrid wood composite panels.

According to the data obtained from the flexural tests, the flexural strengths and flexural modules of the pure panels and hybrid wood composite panels were calculated according to Eq. 1 and Eq. 2, respectively.

$$
\begin{gathered}
\sigma_{\mathrm{f}}=\frac{3 \cdot P_{\mathrm{cr}} \cdot L_{\mathrm{S}}}{2 \cdot b \cdot h^{2}} \\
E_{\mathrm{f}}=\frac{L_{\mathrm{S}}^{3} \cdot m}{4 \cdot b \cdot h^{3}}
\end{gathered}
$$

Where: $P_{\text {cr }}$ denotes the damage load value of the test sample, $L_{\mathrm{S}}$ span width, $b$ is the width of the test sample, $h$ is the height of the test sample and $m$ is the slope of the load-displacement curve.

\subsection{Weibull distribution analysis 2.5. Weibullova distribucija}

In hand-made production, it is not expected that every material produced will have the same physical and mechanical properties. No matter how precise the hand-made production is, the quality of the production

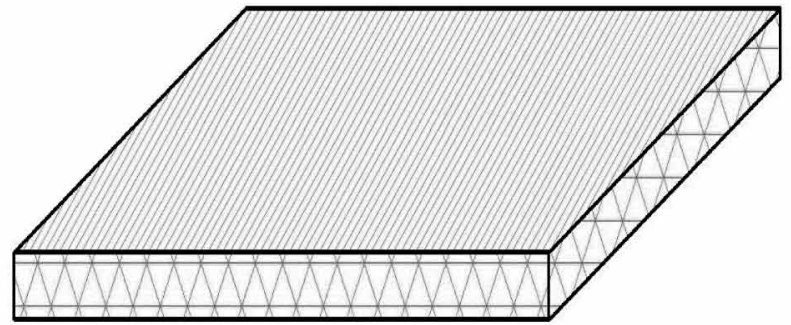

a)

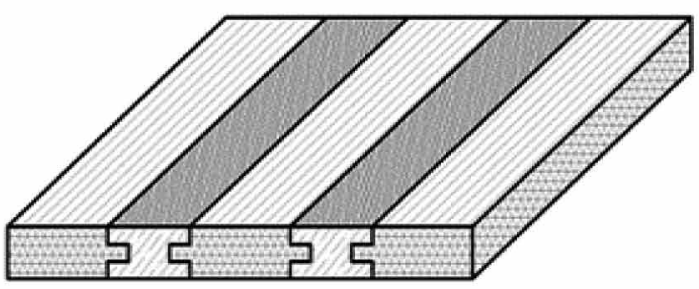

c)

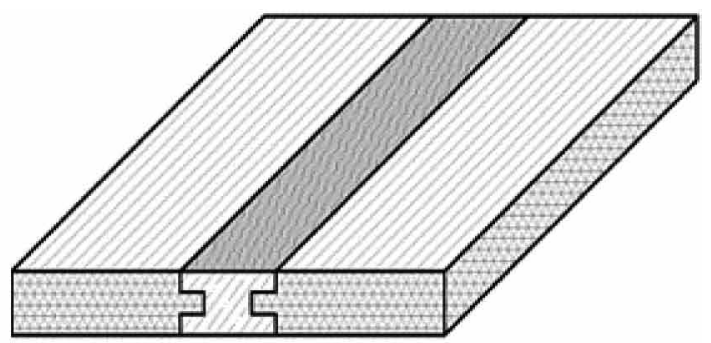

b)

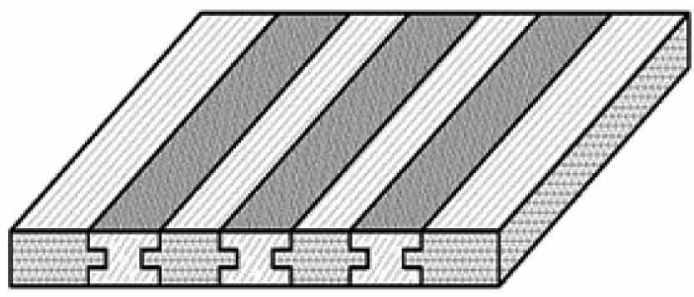

d)

Figure 3 Flexural test specimens: a) pure, b) one-row reinforced, c) two-rows reinforced and d) three-rows reinforced Slika 3. Uzorci za ispitivanje savijanja: a) čisti, b) ojačani jednim bukovim elementom, c) ojačani dvama bukovim elementima, d) ojačani trima bukovim elementima 


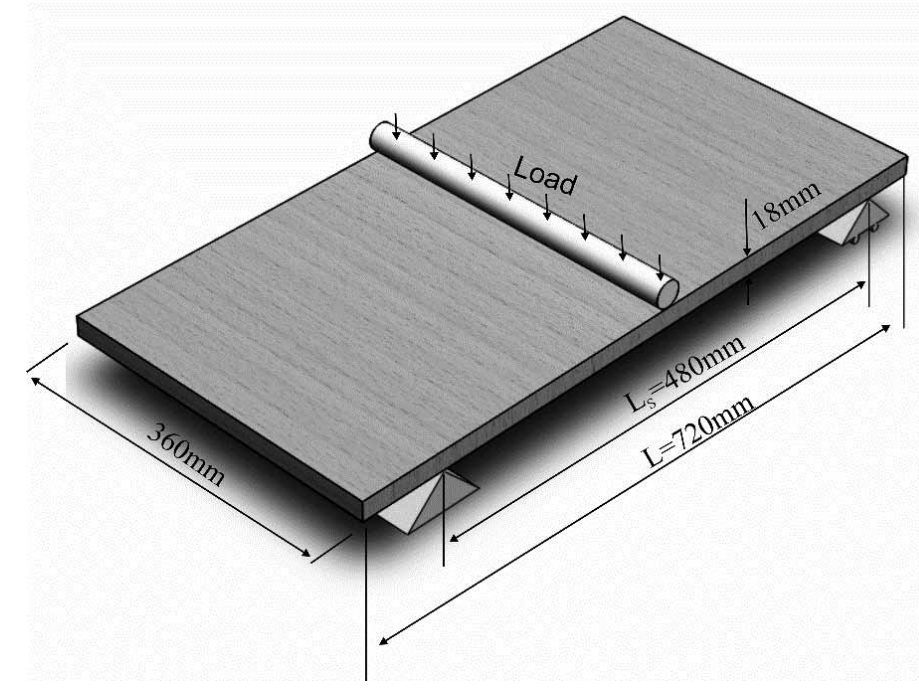

Figure 4 Three-point bending test setup

Slika 4. Ispitivanje savijanja u tri točke

will have lower standards than the production made by sensitive machines. In this framework, the reliability of the test results of hand-made materials is important. In the literature, in most of the experimental studies with repeated tests, the average test results were taken as the main value. The average value does not always represent the actual result. This situation obligates the reliability analysis of the test results. The Weibull distribution, which was put forward by Swedish mathematician Ernst Hjalmar Waloddi Weibull, is one of the most widely used methods in reliability problems (Karabulut et al., 2018)

The most widely used distribution model in the literature is the Weibull statistical analysis with two and three parameters. In the present study, two-parameter Weibull statistical analysis is used to get the variability of flexural strength and flexural modulus of pure and hybrid wood composite panels. The experimental data given in Tables 3 were modeled by a linear curve fit by using Weibull distribution. Weibull distribution, which can be used for damage analysis of wood materials, was considered. The probability density function (PDF) and the associated cumulative density function (CDF) for two-parametric Weibull distribution are given in Eq. 3 and Eq. 4 (Selmy et al., 2014; Karabulut et al., 2018)

$$
\begin{gathered}
P D F(x)=\left(\frac{\beta}{\alpha}\right)\left(\frac{x}{\alpha}\right) \exp \left[-\left(\frac{\beta}{\alpha}\right)^{\beta}\right] \\
C D F(x)=1-\exp \left[-\left(\frac{\beta}{\alpha}\right)^{\beta}\right], \beta \geq 0, \alpha \geq 0
\end{gathered}
$$

Where $x$ presents the random variable value (experimental results such as flexural stress or flexural modulus), $\beta$ is the shape parameter or Weibull slope, and $\alpha$ represents characteristic life or scale parameter. The shape $(\beta)$ and scale $(\alpha)$ parameters, which were obtained by Weibull analysis, are given for pure and hybrid composite wood panels in Tables 3 and 4.

Table 3 Shape and scale parameters of pure and MDF- oriental beech hybrid composite wood panels for flexural test Tablica 3. Parametri oblika i skale za ispitivanje savijanja čiste MDF ploče i hibridne kompozitne drvne ploče MDF - bukovina

\begin{tabular}{|l|c|c|c|c|}
\hline \multirow{2}{*}{$\begin{array}{l}\text { Material type } \\
\text { Vrsta materijala }\end{array}$} & \multicolumn{3}{|c|}{ Flexural stress / Čvrstoća na savijanje } & \multicolumn{2}{c|}{ Flexural modulus / Modul elastičnosti } \\
\cline { 2 - 5 } & $\beta$ & $\alpha, \mathrm{MPa}$ & $\beta$ & $\alpha, \mathrm{MPa}$ \\
\hline Pure MDF / čisti MDF & 8.241 & 22.565 & 11.619 & 3039.427 \\
\hline $\begin{array}{l}\text { One row hybrid } \\
\text { hibrid s jednim elementom }\end{array}$ & 8.393 & 31.941 & 9.408 & 4566.925 \\
\hline Two rows hybrid / hibrids dva elementa & 12.723 & 37.929 & 24.150 & 5060.702 \\
\hline Three rows hybrid / hibrid s tri elementa & 12.830 & 51.013 & 13.612 & 5680.379 \\
\hline
\end{tabular}

Table 4 Shape and scale parameters of pure and chipboard- oriental beech hybrid composite wood panels for flexural test Tablica 4. Parametri oblika i skale za ispitivanje savijanja čiste iverice i hibridne kompozitne drvne ploče iverica - bukovina

\begin{tabular}{|l|c|c|c|c|}
\hline \multirow{2}{*}{$\begin{array}{l}\text { Material type } \\
\text { Vrsta materijala }\end{array}$} & \multicolumn{2}{|c|}{ Flexural stress / Čvrstoća na savijanje } & \multicolumn{2}{c|}{ Flexural modulus / Modul elastičnosti } \\
\cline { 2 - 5 } & $\beta$ & $\alpha, \mathrm{MPa}$ & $\beta$ & $\alpha, \mathrm{MPa}$ \\
\hline Pure Chipboard / čista iverica & 6.718 & 15.874 & 9.555 & 2985.543 \\
\hline $\begin{array}{l}\text { One row hybrid } \\
\text { hibrid s jednim elementom }\end{array}$ & 4.904 & 22.233 & 8.003 & 4427.424 \\
\hline Two rows hybrid / hibrid s dva elementa & 8.287 & 33.006 & 20.983 & 5033.132 \\
\hline $\begin{array}{l}\text { Three rows hybrid } \\
\text { hibrid s tri elementa }\end{array}$ & 7.299 & 49.409 & 33.886 & 5511.588 \\
\hline
\end{tabular}


The reliability function $(R)$ is defined as Eq. 4 is converted to

$$
R(x)=\exp \left[-\left(\frac{x}{\alpha}\right)^{\beta}\right], \beta \geq 0, \alpha \geq 0
$$

by taking the logarithms twice of both sides of Eq. 5 , it becomes

$$
\ln \left[\ln \left(\frac{1}{R(x)}\right)\right]=\beta \ln (x)-\beta \ln (\alpha)
$$

As can be seen from Eq. 6, there is a linear functional relationship between $\ln \left[\ln \left(\frac{1}{R(x)}\right)\right]$ and $\ln (x)$. The slope of this linear function graph gives the shape parameter $\beta$. Scale parameter $\alpha$ is determined from the second term of Eq. 6 (Gorjan and Ambro, 2012).
If the accepted average flexural strength and modulus values are higher than the real strength and modulus values of the material, safety problems can occur in design. Each main strength value, which is equal to real strength value or less, provides an opportunity to create a safer design. In this study, the flexural strength and flexural modulus values, which have $80 \%$ reliability level (R80), were accepted as the main strength and modulus values for the pure and hybrid wood composite panels. The reliability and probability function of Weibull distribution, which belongs to pure and MDF oriental beech hybrid wood composite panels, is illustrated in Figure 5 and 6. Weibull analysis graphics of pure chipboard and chipboard-east beech hybrid wood composite panels are not included due to the similar behavior of the curves.

a)

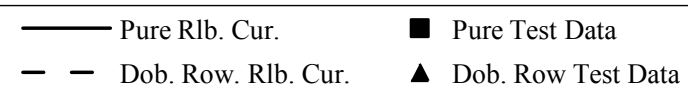
..... Sing. Row Rlb. Cur.

- Sing Row Test Data - - Dob. Row. Rlb. Cur. $\Delta$ Dob. Row Test Data

- - - Three Row Rlb. Cur.

Three Row Test Data

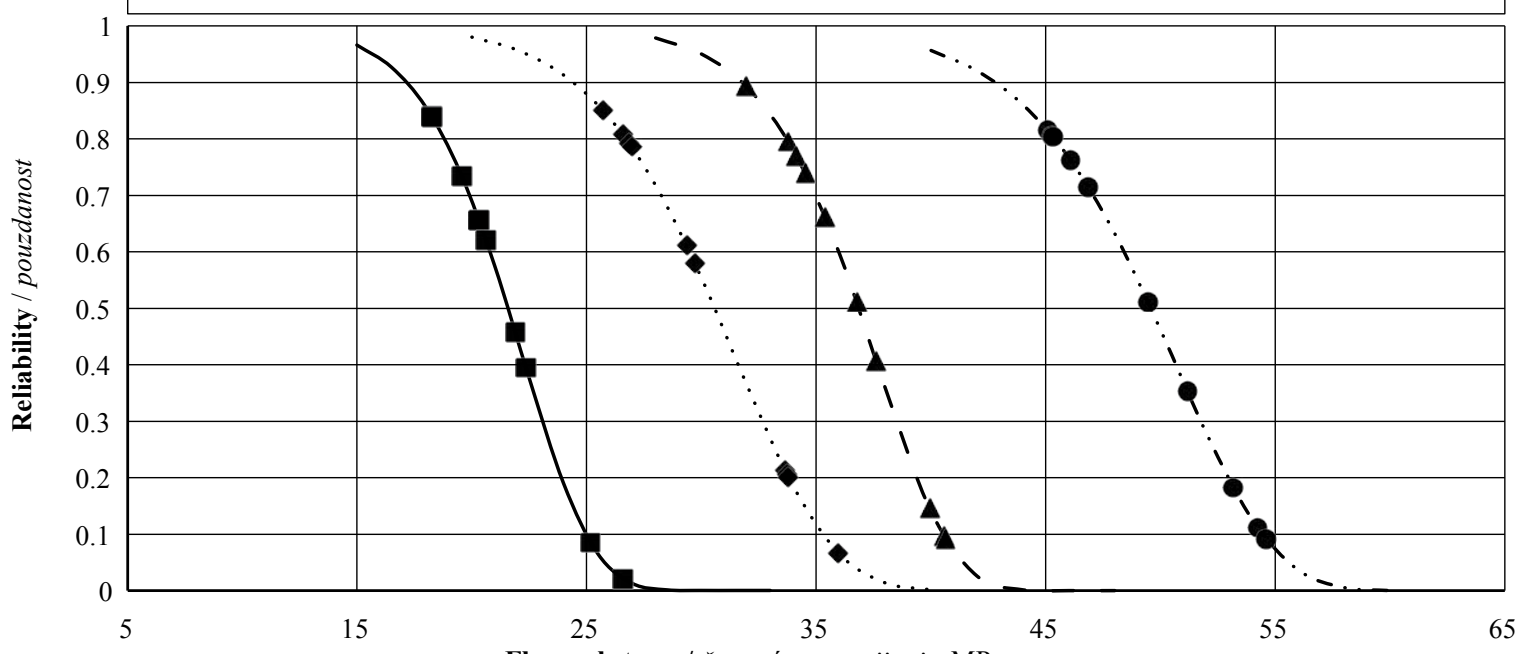

Flexural stress / čvrstoća na savijanje, $\mathrm{MPa}$

b)

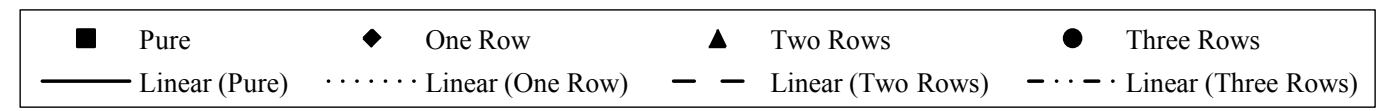

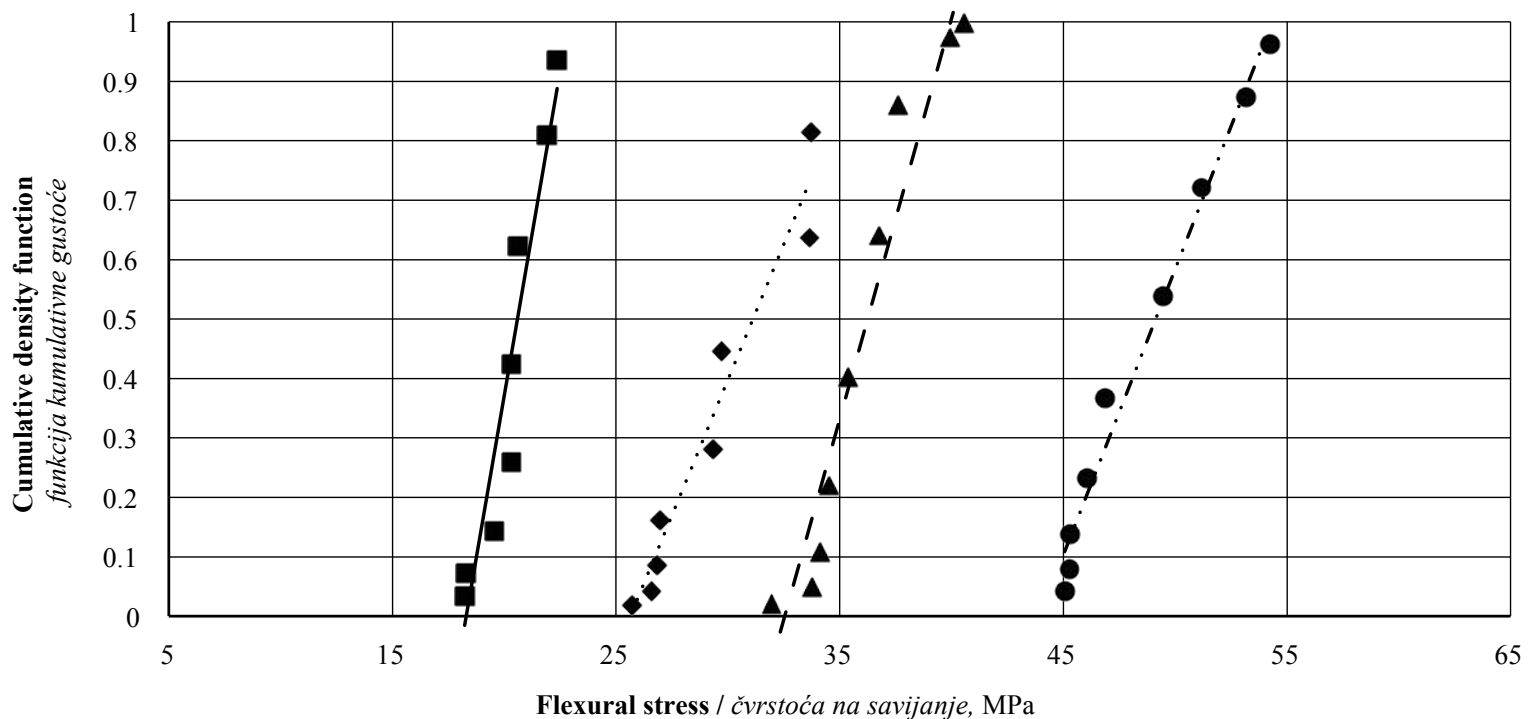

Figure 5 a) Reliability function and b) cumulative density function of pure MDF and MDF - oriental beech hybrid wood composite panels for flexural stress

Slika 5. a) Funkcija pouzdanosti, b) funkcija kumulativne gustoće čiste MDF ploče i hibridne kompozitne drvne ploče MDF - bukovina za čvrstoću na savijanje 
a)

\begin{tabular}{|c|c|c|c|}
\hline $\begin{array}{l}\text { Pure Rlb. Cur. } \\
\text { - Dob. Row. Rlb. Cur. }\end{array}$ & $\begin{array}{ll}\text { - } & \text { Pure Test Data } \\
\text { D } & \text { Dob. Row Test Data }\end{array}$ & $\begin{array}{l}\cdots \cdots \cdot \text { Sing. Row Rlb. Cur. } \\
-\cdots, \cdot \text { Three Row Rlb. Cur. }\end{array}$ & $\begin{array}{l}\text { Sing Row Test Data } \\
\text { Three Row Test Data }\end{array}$ \\
\hline
\end{tabular}

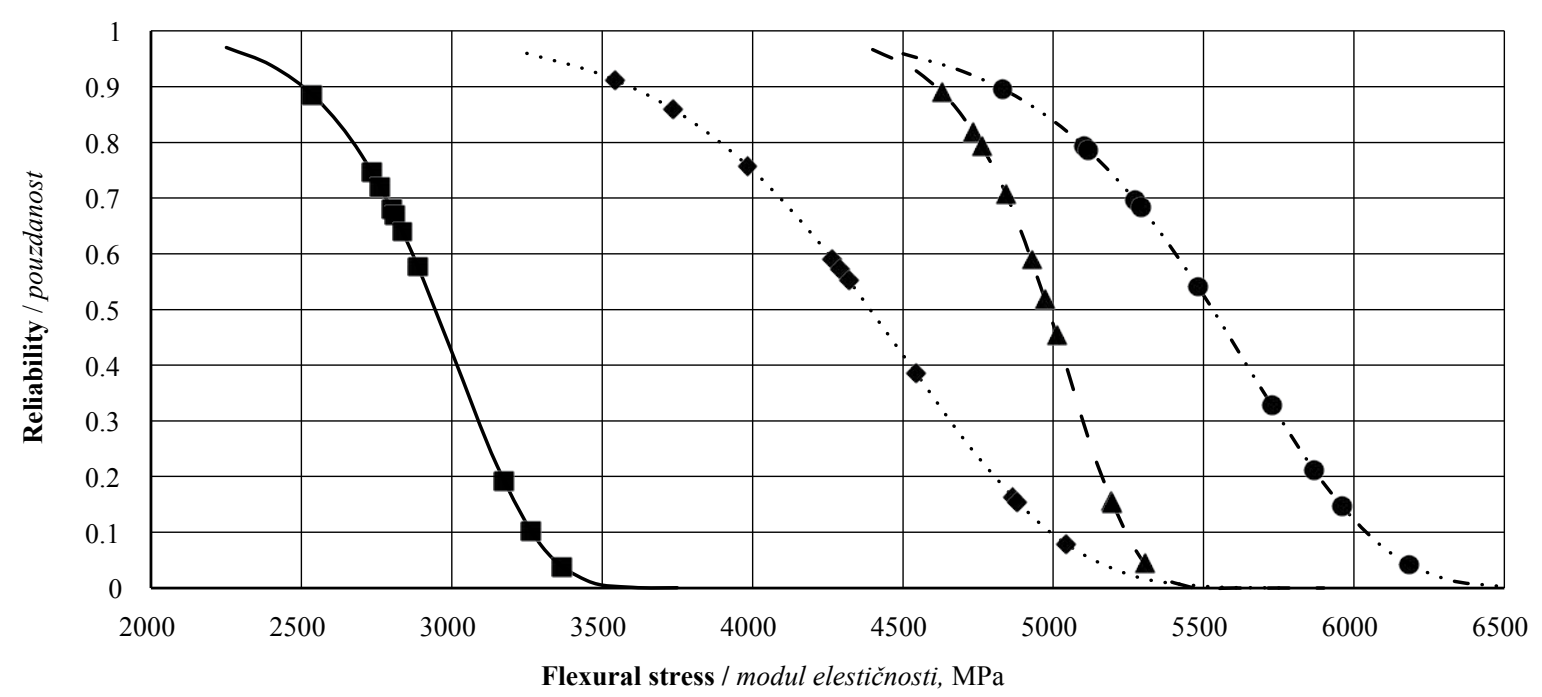

b)
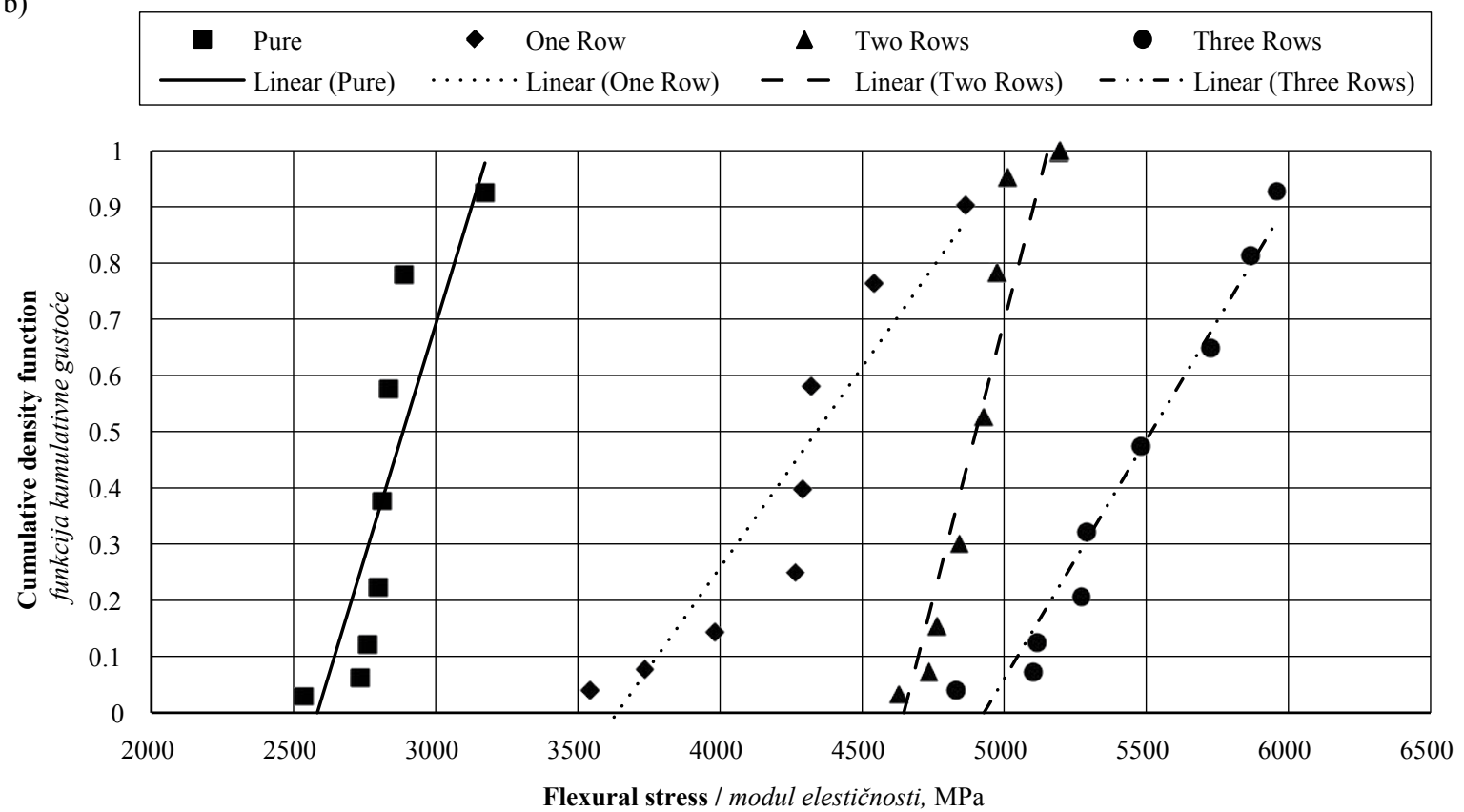

Figure 6 a) Reliability function and b) cumulative density function of pure MDF and MDF - oriental beech hybrid wood composite panels for flexural modulus

Slika 6. a) Funkcija pouzdanosti i b) funkcija kumulativne gustoće čiste MDF ploče i hibridne kompozitne drvne ploče MDF - bukovina za modul elastičnosti

\section{RESULTS AND DISCUSSION 3. REZULTATI I RASPRAVA}

In this study, flexural strength and flexural modulus of pure chipboard, pure MDF, chipboard- oriental beech and MDF- oriental beech hybrid wood composite panels under three-point bending loading were investigated. Within the scope of the study, flexural performances of eight different wooden materials, two pure and six hybrid wood composite panels, were examined. The typical load-displacement behavior of wooden materials under a three-point bending load is given in Figure 7.

Among the test samples, pure chipboard and pure MDF wood samples are the materials with the lowest strength. Under the three-point bending loading, these wooden materials were damaged by breaking brittle. When pure chipboard and pure MDF wood materials were hybridized by using oriental beech, both strength and deformation ability of wood material increased. As seen in Figure 7, both chipboard-east beech and MDFeast beech hybrid wood composite panels showed deformation as they lost their load-bearing capacity after the start of damage. The linear form of the fracture line shows that damage occurred as a brittle and suddenly in pure chipboard and pure MDF wood material (Figure 8a). Since the oriental beech has a natural, flexible, and fibrous structure, the fracture occurred in a ductile form. This can be understood from the zigzag form of the fracture line (Figure 8b). When the number of east 
Karaman, Balcioglu: An Investigation of Flexural Behavior of Pure and Hybrid Wood... .....

a)

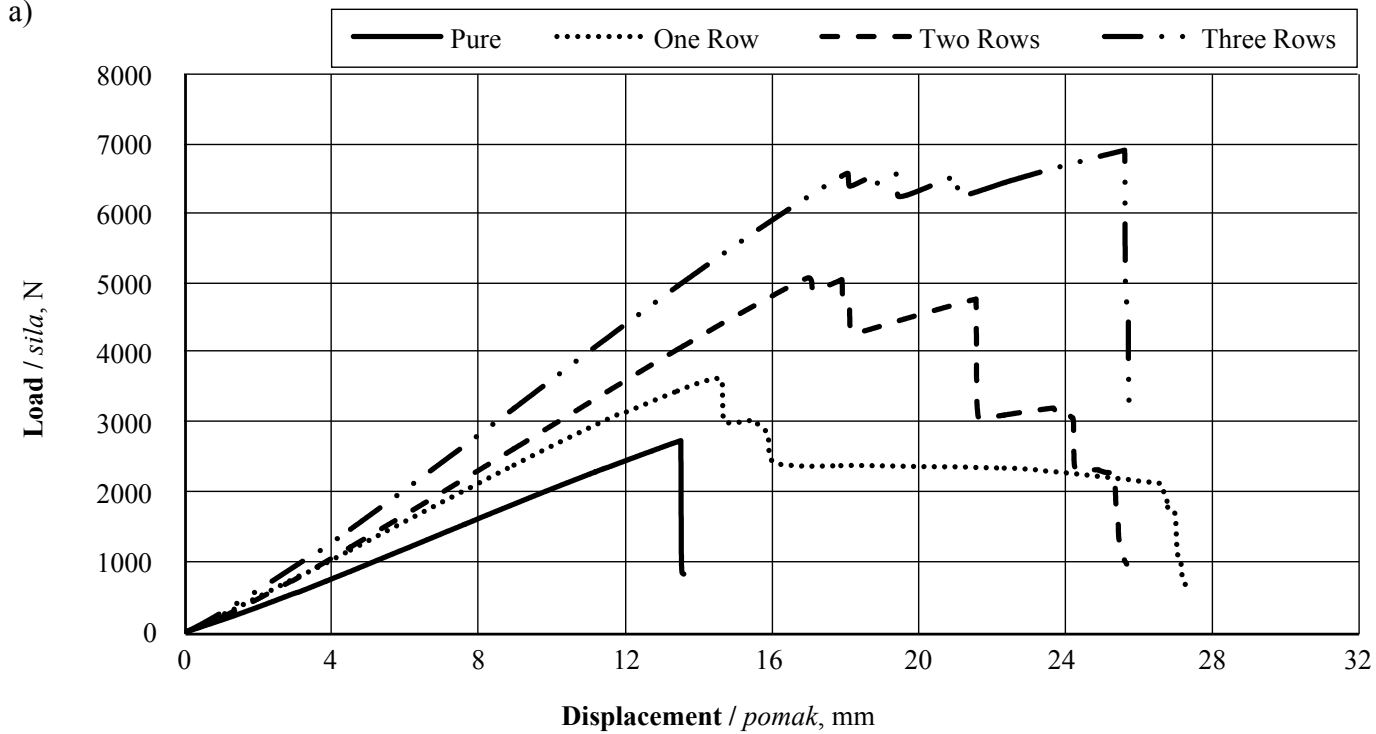

b)

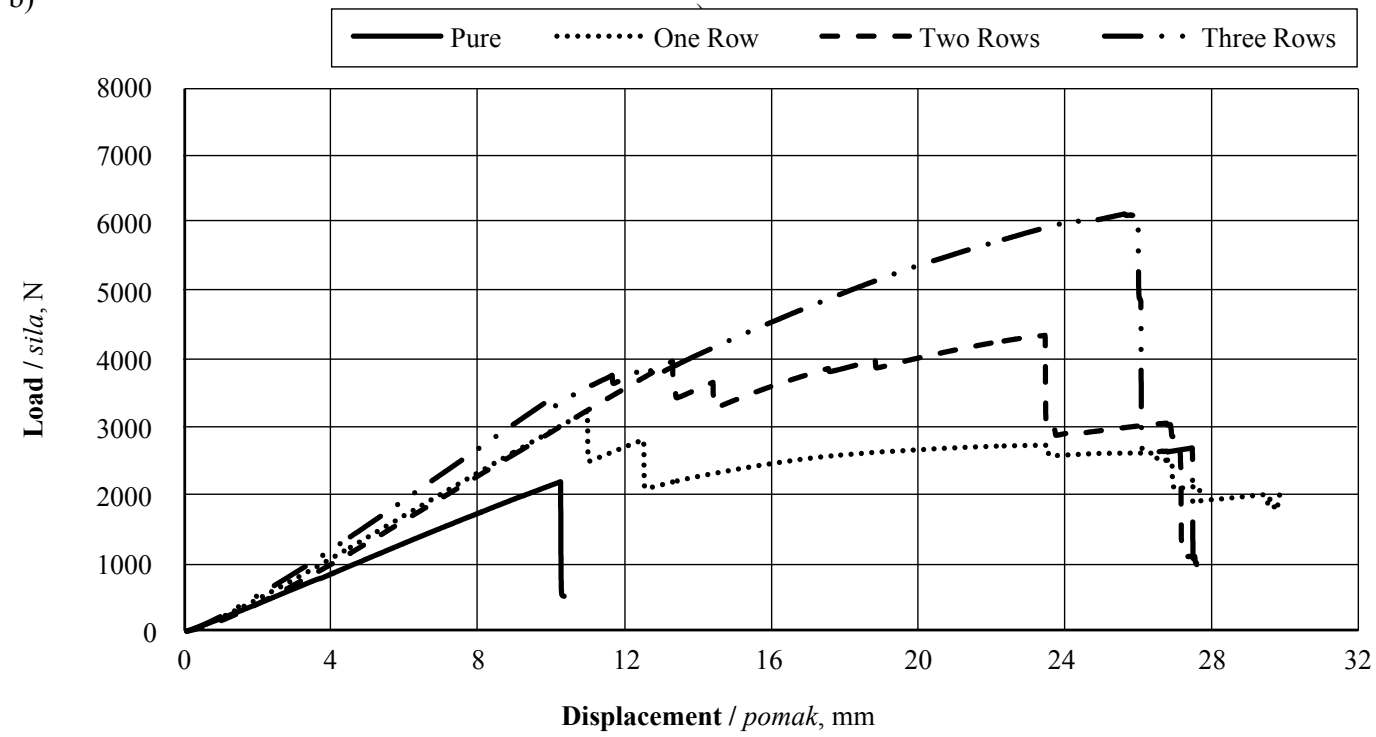

Figure 7 Load-displacement behavior of pure and hybrid wooden materials: a) MDF - oriental beech and b) chipboard - oriental beech

Slika 7. Odnos sile i pomaka čistoga i hibridnoga drvnog materijala: a) MDF - bukovina, b) iverica - bukovina

beech rows used for hybridization increases, the loadcarrying capacity, and deformation ability of hybrid wood composite panels increases in direct proportion.

These experimental results were analyzed according to two-parametric Weibull distribution, and the flexural strength and flexural modulus value of $80 \%$ reliability were accepted as the main value. As seen in Figure 6, at least one test sample data for each material type was obtained with a reliability rate of $80 \%$ and greater. For this reason, after performing Weibull anal-

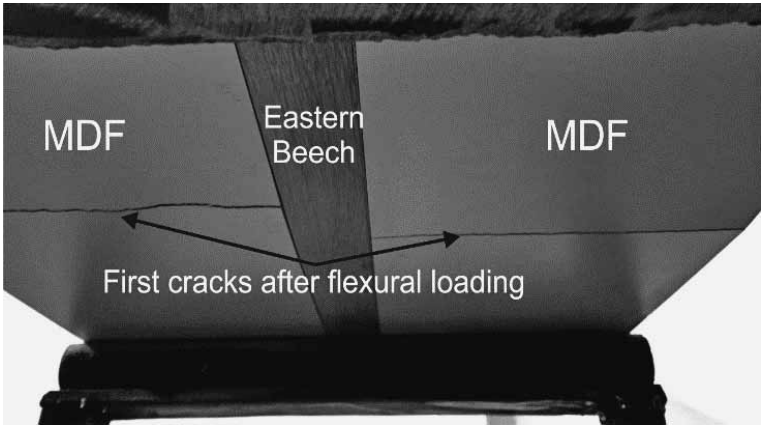

a)

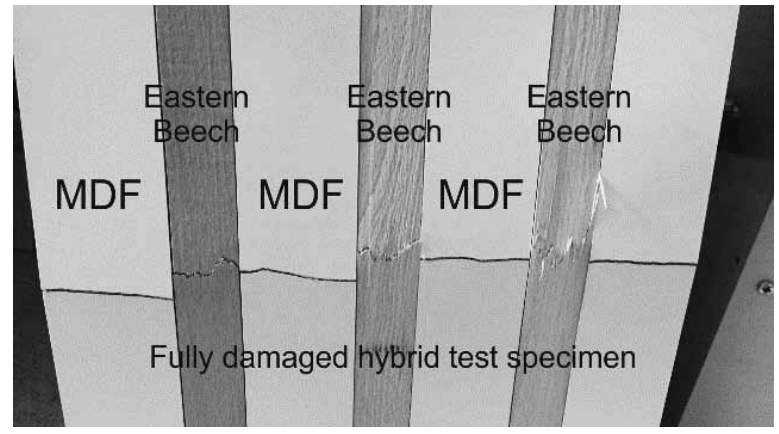

b)

Figure 8 Damaged test samples: a) half damaged and b) fully damaged

Slika 8. Lom na ispitnim uzorcima: a) lom na polovici uzorka, b) lom po cijelom uzorku 
..... Karaman, Balcioglu: An Investigation of Flexural Behavior of Pure and Hybrid Wood...

Table 5 Flexural stress and modulus of pure MDF and MDF- oriental beech hybrid wood composite panels

Tablica 5. Čvrstoća na savijanje i modul elastičnosti čiste MDF ploče i hibridne kompozitne drvne ploče MDF - bukovina

\begin{tabular}{|l|c|c|}
\hline \multicolumn{1}{|c|}{$\begin{array}{c}\text { Material types } \\
\text { Vrsta uzorka }\end{array}$} & $\begin{array}{c}\text { Flexural stress, MPa } \\
\text { Čvrstoća na savijanje, MPa }\end{array}$ & $\begin{array}{c}\text { Flexural modulus, MPa } \\
\text { Modul elastičnosti, MPa }\end{array}$ \\
\hline Pure MDF / čisti MDF & 18.76 & 2668.36 \\
\hline One row hybrid / hibrid s jednim elementom & 26.65 & 3885.42 \\
\hline Two rows hybrid / hibrid s dva elementa & 33.67 & 4751.63 \\
\hline Three rows hybrid / hibrid s tri elementa & 45.31 & 5086.32 \\
\hline
\end{tabular}

Table 6 Flexural stress and modulus of pure chipboard and chipboard- oriental beech hybrid wood composite panels Tablica 6. Čvrstoća na savijanje i modul elastičnosti čiste iverice i hibridne kompozitne drvne ploče iverica - bukovina

\begin{tabular}{|l|c|c|}
\hline \multicolumn{1}{|c|}{$\begin{array}{c}\text { Material types } \\
\text { Vrsta uzorka }\end{array}$} & $\begin{array}{c}\text { Flexural stress, MPa } \\
\text { Čvrstoća na savijanje, MPa }\end{array}$ & $\begin{array}{c}\text { Flexural modulus, MPa } \\
\text { Modul elastičnosti, MPa }\end{array}$ \\
\hline Pure chipboard / čista iverica & 12.69 & 2548.21 \\
\hline One row hybrid / hibrid s jednim elementom & 16.25 & 3652.32 \\
\hline Two rows hybrid / hibrid s dva elementa & 27.54 & 4685.31 \\
\hline Three rows hybrid / hibrid s tri elementa & 39.95 & 4983.52 \\
\hline
\end{tabular}

ysis, the value of $80 \%$ reliability was accepted as the test result. Flexural strength and flexural modulus of pure and hybrid wood composite panels are given in Table 5 and 6 .

In Table 5, the maximum flexural strength of 45.31 MPa was obtained from hybrid wood composite panels with three rows of oriental beech. The minimum value of $18.76 \mathrm{MPa}$ was obtained from pure MDF panels. If the flexural strength value of pure MDF panels is taken as a reference, the hybridization process has achieved an improvement of $141.52 \%$ in the flexural strength. Similarly, the maximum flexural module of $5086.32 \mathrm{MPa}$ and the minimum flexural module of 2668.36 MPa were obtained from MDF- oriental beech hybrid with three rows and pure MDF wood material, respectively. According to these results, it can be said that the hybridization of MDF wood material with oriental beech provides an improvement of $90.61 \%$ in the flexural modulus of the material.

The maximum flexural strength and the maximum flexural modulus value obtained from the tests of pure chipboard and chipboard- oriental beech hybrid wood materials is $35.95 \mathrm{MPa}$ and $4983.52 \mathrm{MPa}$, respectively. Samples subjected to hybridization in three rows with oriental beech, showed the best performance under the three-point bending load. Also, pure chipboard wood material was found to be the material with the lowest strength against the three-point bending load. The minimum flexural strength and flexural modulus values were found to be $12.69 \mathrm{MPa}$ and 2548.21 $\mathrm{MPa}$, respectively. The hybridization process increased the flexural strength and flexural modulus of chipboard wood material up to $214.81 \%$ and $95.57 \%$, respectively.

Since chipboard wood material has a coarse and porous internal structure, its bending strength is lower when compared with MDF material. Therefore, the results obtained in flexural tests have shown that the flexural performance of pure MDF and hybrid structures with MDF is higher. The reason for this may be the density differences, structural properties, mechanical properties of wood materials and different degrees of their adhesion ability.

\section{CONCLUSIONS}

4. ZAKLJUČAK

In this study, hybridization with oriental beech was performed to improve the flexural performance of chipboard and MDF wood materials, which are frequently used in the furniture industry. As a result of the experiments, the test samples, which were combined using different hybridization techniques, showed different flexural characteristics in terms of the bending groups. The data obtained from the flexural tests were analyzed according to the Weibull reliability distribution and the results with an $80 \%$ reliability were accepted as the main value. The results of the analyses showed that, with the hybridization process performed in different techniques on chipboard and MDF, wood materials improved in terms of flexural strength and flexural modulus. Also, it was determined that the type of wood material has an effect on flexural strength and flexural modulus.

The production costs of high strength materials used in engineering structures are expensive. However, the use of low-quality materials creates customer dissatisfaction. For this reason, manufacturers have been searching for materials that are suitable in terms of price/ performance. In recent years, the use of materials with a hybrid structure has been increasing due to their advantages in terms of cost, strength and lightness. The use of hybrid wood products in the furniture industry will both reduce the number of waste-separated products and produce cheaper wood products compared to their relative strength. Besides, considering the functions of furniture and the loads it will bear, knowing the properties of the hybridization methods to be used will positively affect the value and economic life of the furniture.

\section{REFERENCES}

\section{LITERATURA}

1. Altun, S.; Burdurlu, E.; Kiliç, M., 2010: Effect of adhesive type on the bending moment capacity of miter frame corner joints. BioResources, 5 (3): 1473-1483. https://doi.org/10.15376/biores.5.3.1473-1483. 
2. Augeard, E.; Michel, L.; Ferrier, E., 2018: Experimental and analytical study of the mechanical behavior of heterogeneous glulam - concrete beams and panels assembled by a specific treatment of wood. Construction and Building Materials, 191: 812-825. https://doi.org/10.1016/j.conbuildmat.2018.10.038.

3. Baszeń, M., 2017: Semi-rigid behavior of joints in wood light-frame structures. Procedia Engineering, 172: 88-95. https://doi.org/10.1016/j.proeng.2017.02.022.

4. Çağatay, K.; Efe, H.; Kasal, A., 2012: The effects of wood species and joint technique on bending moment capacity and elasticity of T-type furniture joints. Journal of Polytechnic, 15 (4):161-169.

5. Dourado, N.; Pereira, F. A. M.; Lousada, J. L.; de Moura, M. F. S. F., 2019: Experimental and numerical analyses of wood boards joining using wood-pin connectors. Construction and Building Materials, 222: 556-565. https://doi.org/10.1016/j.conbuildmat.2019.06.179.

6. Edgars, L.; Kaspars, Z.; Kaspars, K., 2017: Structural performance of wood based sandwich panels in four point bending. Procedia Engineering, 172: 628-633. https://doi.org/10.1016/j.proeng.2017.02.073.

7. Efe, H.; Özen, E.; Danacı, E.; Kasal, A.; Demirci, S., 2014: Effect of joint technique on moment capacity of L-type furniture corner joints for case furniture constructed. Kastamonu Üniversitesi Orman Fakültesi Dergisi, 14 (1): 15-23.

8. Efe, H.; Özen, E.; Danac1, E.; Kasal, A.; Demirci, S., 2015: Comparison of the withdrawal strength of different joint techniques for wooden end to end joints. Karabuk University Journal of Forestry Faculty, 12 (1): 80-89.

9. Eshaghi, S.; Faezipour, M.; Taghiyari, H. R., 2013: Investigation on lateral resistance of joints made with drywall and sheet metal screws in bagasse particleboard and comparison with that of commercial MDF. Maderas. Ciencia y tecnología, 15 (2): 127-140. https://doi.org/10.4067/S0718-221X2013005000011.

10. Gorjan, L.; Ambro, M., 2012: Bend strength of alumina ceramics : A comparison of Weibull statistics with other statistics based on very large experimental data set. 32 : 1221-1227. https://doi.org/10.1016/j.jeurceramsoc.2011.12.010.

11. Karabulut, N.; Aktaş, M.; Balcıoğlu, H. E., 2018: Surface modification effects on the mechanical properties of woven jute fabric reinforced laminated composites. Journal of Natural Fibers, 16 (5): 629-643.

https://doi.org/10.1080/15440478.2018.1431995.
12. Kasal, A.; Eckelman, C. A.; Haviarova, E.; Erdil, Y. Z.; Yalcin, I., 2015: Bending moment capacities of L-shaped mortise and tenon joints under compression and tension loadings. BioResources, 10 (4): 7009-7020. https://doi.org/10.15376/biores.10.4.7009-7020.

13. Likos, E.; Haviarova, E.; Eckelman, C. A.; Erdil, Y. Z.; Ozcifci, A., 2012: Effect of tenon geometry, grain orientation, and shoulder on bending moment capacity and moment rotation characteristics of mortise and tenon joints. Wood and Fiber Science, 44 (4): 462-469.

14. Ozgan, E.; Kap, T., 2008: Investigating the performance of the L type frame construction corner junctions exposed to the inclining moment. Journal of the Faculty of Engineering and Architecture of Gazi University, 23 (2): 385-394.

15. Cai, Z.; Ros, R. J., 2010: Mechanical properties of woodbased composite materials. In: Wood handbook: Wood as an engineering material. Madison, WI: US Dept. of Agriculture, pp. 1-12.

16. Selmy, A. I.; Azab, N. A.; El-baky, M. A. A., 2014: Statistical analysis of monotonic mechanical properties for unidirectional glass fiber (U)/ random glass fiber (R)/ epoxy hybrid and non-hybrid polymeric composites. Journal of Composite Materials, 48 (4):455-469. https://doi.org/10.1177/0021998312474046.

17. Tankut, A. N.; Tankut, N., 2009: Investigations the effects of fastener, glue, and composite material types on the strength of corner joints in case-type furniture construction. Materials \& Design, 30 (10): 4175-4182. https://doi.org/10.1016/j.matdes.2009.04.038.

18. Tas, H. H., 2011: The effect of L-type corner joints on load carrying capacity in case furniture. SDU Faculty of Forest Journal, 12: 126-130.

19. ***TSE2478, 1976: Wood-determination of modulus of elasticity in static bending. Ankara.

\section{Corresponding address:}

\section{H. ERSEN BALCIOGLU}

Usak University

Engineering Faculty

Department of Mechanical Engineering

Usak, TURKEY

e-mail: ersenbalcioglu06@gmail.com 